\title{
Notes
}

\section{Applying Accelerated Growth Production Practices to American Chestnut}

\author{
Ricky M. Bates, ${ }^{1}$ \\ James C. Sellmer, ${ }^{1}$ \\ Tracey L. Harpster, ${ }^{2}$ and \\ Larry J. Kuhns ${ }^{3}$
}

Additional InDEX words. establishment, container production, leaf scorch, Castanea dentata

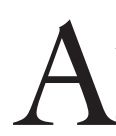

merican chestnut (Castanea dentata) once made up more than one quarter of the hardwood trees in eastern U.S. forests (Griffin, 1986). The introduction of chestnut blight (Cryphonectria parasitica) to North America in 1904 decimated the native population and few trees remained in the wild by 1950 (Anagostakis, 1996). Today most chestnut trees are little more than stumps that sprout and occasionally flower, but rarely produce fruit.

In 1995, the Pennsylvania Chapter of the American Chestnut Foundation (PC-TACF) initiated a backcross breeding program to produce blight-resistant american chestnuts adapted to the northeastern U.S. Asuccessful breeding and disease-screening program requires that all possible progeny representing

\footnotetext{
${ }^{1}$ Assistant professor, Dept. of Horticulture, The Pennsylvania State University, University Park, PA 16802

${ }^{2}$ Graduate student, Dept. of Horticulture, The Pennsylvania State University, University Park, PA 16802.

${ }^{3}$ Professor, Dept. of Horticulture, The Pennsylvania State University, University Park, PA 16802.
}

the crosses survive and can be screened. The PC-TACF's approach to seed germination and seedling production relied exclusively on field planting of seeds in the fall allowing natural stratification and germination, or direct seeding in the spring after controlled stratification. Two obstacles to the breeding program were 1) the 5- to 8-year growth period required for a tree to sexually mature, and 2) the loss of breeding stock to wildlife feeding. Accelerated growth production systems (AGPS) are capable of producing large tree seedlings within a relatively short time period (Arnold and Struve, 1989; Struve, 1990). Use of AGPS to produce large, containerized american chestnut for outplanting may serve to improve survivability and provide growers with stock better able to withstand deer browsing. The project reported upon here was initiated to assess the performance of american chestnut in AGPS and to compare growth and survival of trees produced using AGPS and direct-seeded methods.

\section{Description of the process}

American chestnut seeds representing six seed lots were received from PC-TACF in October 1998. Seeds were placed in polyethylene bags containing moist peatmoss, in a walk-in cooler maintained at $5^{\circ} \mathrm{C}\left(41.0^{\circ} \mathrm{F}\right)$. Seed was monitored for mold development every 2 weeks. In early Mar. 1999, after 19 weeks of stratification, one seed per pot was planted into Spin-out (Griffin Corp, Valdosta, Ga. ) treated \#40 [655.5- $\mathrm{cm}^{3}$ $\left(40\right.$-inch $\left.{ }^{3}\right)$ ] DeePots (Stuewe and sons, Inc., Corvallis, Ore.) filled with Sunshine \#4 media (Fisons Horticulture, Inc., Vancouver, B.C.) and placed on benches in a greenhouse. By 16 Mar., seeds of several lots had germinated and seedlings emerged. During the first month, a fertilizer solution was applied twice weekly to plants with 60 $\mathrm{mg} \cdot \mathrm{L}^{-1}(\mathrm{ppm})$ nitrogen using Peter's
21-7-7 (21N-3.1P-5.8K; Scotts-Sierra Horticultural Products, Marysville, Ohio) after which the $\mathrm{N}$ rate was increased to $90 \mathrm{mg} \cdot \mathrm{L}^{-1}$. Seedlings were transplanted on 20 May 1999 into \#3 $\left[0.01-\mathrm{m}^{3}\left(0.353-\mathrm{ft}^{3}\right)\right]$ Spin-out treated nursery pots containing Fafard \#52 (Fafard, Inc., Anderson, S.C.) and placed under $70 \%$ shade, at the Pennsylvania State University Horticulture Research Farm at Rock Springs, Pa. (Rock Springs). Plants were irrigated with an intermittent spray system for 45 min daily, delivered in three 15 - min durations from 0600 to $0715 \mathrm{HR}$. Plants were top-dressed with $53 \mathrm{~g}$ (1.9 oz) of Sierra 17-6-10 (17N-2.7P-8.3K; Scotts-Sierra Horticultural Products, Marysville, Ohio) and liquid fertilization discontinued on 4 June. Plants were prepared for overwintering by watering to saturation, placing containers on their sides, and covering with a styrofoam blanket in an unheated polyhouse on 22 Nov. 1999. Before covering, rodenticide was placed in 10.2-cm-diameter (4-inch) polyvinylchloride pipe sections. Plants were uncovered and set upright on 25 Feb. 2000. On 21 June 2000, trees were manually transplanted into a Murrill Channery silt loam soil at Rock Springs.

Direct-seeded chestnuts were planted at Rock Springs on 15 Nov. 1998. Glyphosate was applied to the site in strips before planting to kill existing vegetation. Irrigation was supplied to seedlings periodically during the 1999 growing season when rainfall was insufficient to maintain vigorous growth. Seedlings were planted in a completely randomized design and were protected from deer predation by electric fencing.

During early September 1999 , plant height, stem caliper, leaf area and leaf numbers were recorded on 15 trees randomly selected from each production system. Plant height was measured to the apex of the tallest shoot and stem caliper was measured $5.1 \mathrm{~cm}$ ( 2 inches) above the soil line. Leaf number was recorded for each plant and average leaf area was determined by measuring each fully expanded leaf on each tree using a portable area meter (LI-COR, Lincoln, Nebr.). The number of surviving plants was recorded in August 2000.

\section{Observations}

Tree height after one season in the accelerated growth production system averaged $144.78 \mathrm{~cm}$ (57.0 inches) 
Table 1. Growth characteristics and survivability of american chestnut direct seeded and produced in an accelerated growth system after one growing season.

\begin{tabular}{lccccc}
\hline $\begin{array}{l}\text { Production } \\
\text { system }\end{array}$ & $\begin{array}{c}\text { Plant } \\
\text { ht } \\
\text { (inches) }^{\mathrm{w}}\end{array}$ & $\begin{array}{c}\text { Stem } \\
\text { caliper } \\
(\mathbf{m m})^{\mathrm{z}, \mathrm{w}}\end{array}$ & $\begin{array}{c}\text { Avg } \\
\text { leaf area } \\
\left(\mathbf{c m}^{2}\right)^{\mathrm{w}}\end{array}$ & $\begin{array}{c}\text { Avg } \\
\text { leaf } \\
\text { no. }\end{array}$ & $\begin{array}{c}\text { Seedling } \\
\text { survival } \\
(\%)^{\mathrm{y}}\end{array}$ \\
\hline Accelerated growth system & $57.0 \mathrm{a}$ & $7.2 \mathrm{a}$ & $84.5 \mathrm{a}$ & $23 \mathrm{a}$ & $86.7 \mathrm{a}$ \\
Field, direct seeded & $19.5 \mathrm{~b}$ & $3.1 \mathrm{~b}$ & $76.1 \mathrm{a}$ & $13 \mathrm{~b}$ & $46.7 \mathrm{~b}$ \\
\hline
\end{tabular}

${ }^{2}$ Measured $5.1 \mathrm{~cm}$ (2 inches) above soil line.

${ }^{y}$ Measured in 2000 , after 2 years in the field.

${ }^{x}$ Mean in a column not followed by common letters are significantly different by Tukey's standardized range test, $(P \leq 0.05)$.

${ }^{\mathrm{w}} 1.0$ inch $=2.54 \mathrm{~cm}, 1.0 \mathrm{~mm}=0.039 \mathrm{inch}, 1.0 \mathrm{~cm}^{2}=0.155 \mathrm{inch}^{2}$

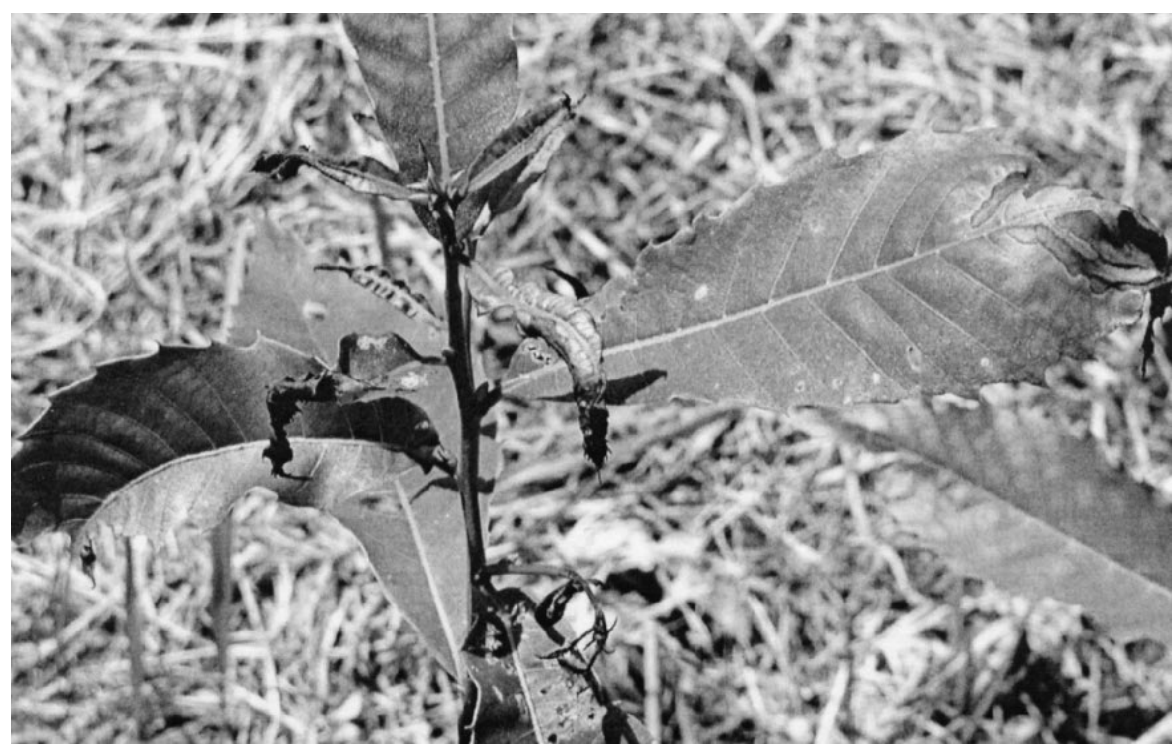

Fig. 1. Marginal leaf scorch on new and fully expanded american chestnut leaves grown in an accelerated growth production system following transplanting to the field.

compared to $49.53 \mathrm{~cm}$ (19.5 inches) for direct seeded trees (Table 1). Plants exhibited larger caliper and greater leaf number than seeded field grown plants scorch (Fig. 1) and depressed growth after transplanting to the field. Leaf scorch was more pronounced among seedlings transplanted from DeePots compared to \#3 containers used in other trials (data not shown). Some seedlings also developed bleaching of leaf tissue after transplanting. These problems may be related to inadequate cuticular wax development during production in the system and photodegradation of the chlorophyll due to insufficient adaptation to high field light conditions.

Results of this study demonstrate that an accelerated growth production system can be used to produce chestnut seedlings more rapidly than traditional methods. Cost comparisons of the two methods were not included in this study. Future studies will investigate differences between the two systems in long-term survivability, time-to-flower, and techniques to reduce leaf scorch and improve plant establishment.

\section{Literature cited}

Anagostakis, S.L. 1996. An historical reference for chestnut introductions into North America. J. Amer. Chestnut Found. 9(2):17-23.

Arnold, M.A. and D.K. Struve. 1989. Growing green ash and red oak in $\mathrm{CuCO}_{3}$-treated containers increases root regeneration and shoot growth following transplanting. J. Amer. Soc. Hort. Sci. $114: 402-406$.

Griffin, G.J. 1986. Chestnut blight and its control. Hort. Rev. 8:291-336.

Struve, D.K. 1990. Turning copper into gold. Amer. Nurseryman 172: 114-125. 